\title{
The Level of Perceptions toward Agriculture Land Development Programme among Orang Asli in Pahang, Malaysia
}

\author{
Halilah Hamid ${ }^{1}$, Asnarulkhadi Abu Samah ${ }^{2}$ \& Norsida Man ${ }^{3}$ \\ ${ }^{1}$ Institute for Social Science Studies, Universiti Putra Malaysia, Malaysia \\ ${ }^{2}$ Department of Social and Development Science, Faculty of Human Ecology, Universiti Putra Malaysia, \\ Malaysia \\ ${ }^{3}$ Department of Agribusiness and Information System, Faculty of Agriculture, Universiti Putra Malaysia, \\ Malaysia
}

Correspondence: Halilah Hamid, Institute for Social Science Studies, 43400, Universiti Putra Malaysia, Malaysia. E-mail: halilahhamid@yahoo.com

Received: April 8, 2013 Accepted: June 3, 2013 Online Published: August 1, 2013

doi:10.5539/ass.v9n10p151 URL: http://dx.doi.org/10.5539/ass.v9n10p151

\begin{abstract}
In Malaysia, the government has embarked a diverse and comprehensive development programmes in efforts to develop the life of Orang Asli, the indigenous community in peninsular Malaysia. These programmes include providing budget allocation for houses for the hardcore poor, financial savings scheme, basic amenities and community infrastructure and plantation. Agriculture Land Development Programme (ALDP) was claimed by the Department of Orang Asli Development (JAKOA) as main Department activities in an effort to eradicate poverty among the Orang Asli community. The ALDP is still emphasizing in $10^{\text {th }}$ Malaysia Plan as the main tool to address the high incidence of poverty among Orang Asli and certain budget was allocated for this programme. One of the factors that can influence the successful rate of development programme is participant's perception. Therefore, the objective of this study is to determine the level of perception of Orang Asli toward ALDP oil palm plantation. This is a quantitative descriptive study whereby data were gathered using a questionnaire. Data was analysed using the SPSS for descriptive and correlation analysis involved 170 respondents. Overall, the finding shows that the level of perception is moderate. Some recommendations were made due to results of study in order to improve the ALDP in future.
\end{abstract}

Keywords: Orang Asli, perception, agriculture land development programme

\section{Introduction}

The 'Orang Asli' are the indigenous minority people of Peninsular Malaysia. The term 'Orang Asli' this is literally translated as 'Original People' known as forest-dwelling aborigines and forest-dependent community (Lim, 2003). They constitute a minority community making up approximately $0.58 \%$ of the total population of Malaysia (28.31 million in 2009) (Department of Statistic Malaysia, 2010). There are three main Orang Asli tribes namely; Negrito, Senoi and Proto-Malay which are further sub-divided into eighteen sub-ethnic groups. Among Senoi, there are six sub-ethnic groups namely the Temiar, Semai, Jahut, Che Wong, Semoq Beri and Mahmeri. As for the Negrito, there are six-ethnic sub groups - Kensiu, Kintaq, Jahai, Mendriq, Bateq and Lanoh. While, the Proto-Malay group consists of six-ethnic sub groups - Temuan, Jakun, Semelai, Orang Kuala, Orang Seletar and Orang Kanaq. The Negrito, also referred to as Semang, is the oldest inhabitant of Peninsular Malaysia (Edo \& Kamal, 2004).

The Department of Orang Asli Development (JAKOA) is the main agency responsible for Orang Asli. The most prominent development program initiated by JAKOA for Orang Asli is Resettlement Plan Scheme or also known as "regroupment schemes" and locally known as Rancangan Pengumpulan Semula (RPS). In this scheme, the participants get the provision of residential homes, integrated infrastructures and facilities such house, school, village clinic, halls, mosque and entrepreneur business shop lots. By year 1999, there were eighteen RPS in the country, six in Perak, seven in Pahang, three in Kelantan and one is in Johor. Each family gets ten acres of land planted either with rubber, oil palm, and fruit orchard, and two acres for housing and subsistence crops (Jimin et al., 1983) under Agriculture Land Development Programme (ALDP). Participating in commercial crops, the 
Orang Asli earns and at same time can work as plantation workers (JAKOA, 2010). The funding agencies that undertake such programme are Rubber Industry Smallholder Development Authority (RISDA) and Federal Land Consolidation and Rehabilitation Authority (FELCRA). In fact, it is the cooperation between JAKOA with these agencies since mid-1990s helped in implementing and developing the RPS (Nicholas, 2000).

Perception can influence the successful rate of development programme. According to Jalaluddin (2003), perception is an experience of objects, events or links obtained that can conclude by someone which could be transform as information and interpret it. While Kotler (2000) explained perception as the process of how someone elects, manages and interprets the entry of information to create a description of meaningful whole. The concept of perception is a key dimension in understanding the diffusion of ideas. Although a new idea may be regarded as advantage by expert in some field, a particular actor may not perceive the innovation in a similar manner. Perception is the way in which an individual responds to any sense or impression which he detects (Lindesmith \& Strauss, 1956).

Mohd Fauzi (2002) in his study revealed that the positive perception towards factors which influenced the process of nation-building in Malaysia and the respondents have different perceptions on the process of nation-building and on development based on political, economic and social outlook. Another finding suggests that it is not an objective profitability but the adopter's perception of profitability that determines the rate of adoption (Rogers, 2003) shows that the perception is important aspect to be observed. The researcher believes that positive perception toward ALDP can influence the rate of impact. The perceptions of Orang Asli towards ALDP objectives, management by agriculture agencies and other aspects are still outstanding. Their perceptions is important since it shows their responds and perspective to improve the programme.

Harun et al., (2010) discovered that the Orang Asli in RPS Runchang have a positive perception towards ALDP as long as their lifes are getting better. They enjoy the assistance and financial benefits from agriculture project by FELCRA. For them, cultivation practices are able to secure their livelihood compared to depending on forest products. However, they perceived that in long term, this programme conducted by FELCRA would not be able to bring them out of poverty. Lim (1997) in his writing, mentioned that the Orang Asli in ALDP perceived that RISDA has the credible to develope their traditional land compared to FELCRA. They feel that they do not lost their land possession if RISDA develop the land. Among the participant in ALDP, they should have good and high perception toward ALDP to show their confidence on the programme and development agencies in order to help them gain more benefits from their participation.

Based on the explanations, the researcher believes that perceptions of Orang Asli towards ALDP is an important aspect to be observed.

\section{Methodology}

This is a quantitative descriptive study whereby data were gathered using a questionnaire. The study was carried out in the state of Pahang which has the highest number of Orang Asli population in Peninsular Malaysia. Based on 2004 census the number is about 67,506 people (JAKOA, 2011). The location of study is RPS that were involved in oil palm plantation namely as RPS Kedaik, RPS Bukit Serok, RPS Runchang and RPS Buluh Nipis. These four RPS has the biggest number of population which consist almost 955 total dividend receivers (JAKOA, 2010). The basic information about the selected locations of study as shown in Table 1.

Table 1. Background of the selected RPS in the study

\begin{tabular}{|c|c|c|c|}
\hline RPS & Program Effectiveness & $\begin{array}{l}\text { Monthly Dividend } \\
\text { January 2011) }\end{array}$ & Amount (on \\
\hline Kedaik & Increased in the income & RM800.00 & \\
\hline Bukit Serok & Increased in the income & RM800.00 & \\
\hline Runchang & Increased in the income & RM 700.00 & \\
\hline Buluh Nipis & $\begin{array}{l}\text { Participants did not get receive the income from } \\
\text { the oil palm activity }\end{array}$ & RM400.00 & \\
\hline
\end{tabular}

Source: Abdul Jamak et al., (2003) and Survey (2011) 
To determine the appropriate number for the required analyses, the G-Power analysis was employed. The sample size suggested using this power analysis yielded a recommended sample size of 0.178 equal to 170 respondents. This study used the simple random sampling method where each and every member of the population has an equal and independent chance of being selected. Table 2 shows the distribution of respondents involved in this study. Most of respondents were from RPS Bukit Serok that is 46 (27.1\%), RPS Kedaik 44 (25.9\%), RPS Runchang with the 43 (25.3\%) and Buluh Nipis with 37 (21.8\%) respectively.

Table 2. The distribution of respondents by RPS

\begin{tabular}{lcc}
\hline Name of RPS & Frequency $(\mathrm{n}=170)$ & Percentage $(\%)$ \\
\hline Kedaik & 44 & 25.9 \\
Bukit Serok & 46 & 27.1 \\
Runchang & 43 & 25.3 \\
Buluh Nipis & 37 & 21.8 \\
\hline
\end{tabular}

The researcher developed instrument for this study, as there had been no standard instrument developed by the previous researcher to be followed totally. This part is about respondents perceptions toward ALDP that consist 3 sections that are perception toward objective of ALDP, development agencies and advantages of ALDP. By using 5-Likert Scale, total of statement in this part is 20 items and respondents were asked to rate their opinion based on the score given. The Cronbach's Alpha for this part is 0.750 , therefore the results indicate that scale were considered to be reliable and acceptable for further analysis. The Likert Scale is designed to examine how strongly subjects agree or disagree with the statements on a 5 -point scale that are $1=$ 'strongly disagree', $2=$ 'disagree', $3=$ 'undecided', $4=$ 'agree' and $5=$ 'strongly agree'. The level of perception was calculated based on minimum and maximum values score which divided into a mean of $1.00-2.33$ indicated low level, a mean of $2.34-3.67$ indicated moderate level and a mean of $3.68-5.00$ indicated high level for every item.

\section{Results}

As mention earlier, this study only involved respondents who participate in the oil palm ALDP. The average age of respondents is around 47 years old and above. About 32.9 percent (56 respondents) were between $41-50$ years old and 26.5 percent ( 45 respondents) for range of age between $31-40$ years old as show in Table 3 . Most of the respondents are male $(81.2 \% ; 138$ respondents) and $32(18.8 \%)$ were female respondents. Majority of them are Jakun, a Proto-Malay sub-ethnic 168 (98.8\%) and 2 (1.2\%) are Semelai.

This study revealed almost 52 percent of respondents did not attend formal education. Almost 40 percent or 67 of respondents attended primary school. Only small number that is $2(1.2 \%)$ achieved tertiary level of education. More than half of them that is $99(58.2 \%)$ of respondents gain RM $501-$ RM 1000 per month. The highest monthly income received was than RM2500 per month with only $2(1.2 \%)$ of respondent. Majority of respondents, $(65.0 \%$; 106 respondents) has the household below than 6 people. Only $1(0.6 \%)$ of respondents has more than 15 dependents.

Table 3. Demographic profile of respondents $(n=170)$

\begin{tabular}{|c|c|c|c|}
\hline & Characteristic & Frequency (n) & Percentage $(\%)$ \\
\hline \multicolumn{4}{|c|}{ Age (years) } \\
\hline$<30$ & & 10 & 5.9 \\
\hline $31-40$ & & 45 & 26.5 \\
\hline $41-50$ & & 56 & 32.9 \\
\hline $51-60$ & & 41 & 24.1 \\
\hline $61-70$ & & 11 & 6.5 \\
\hline$>71$ & & 7 & 4.1 \\
\hline Mean $=47.18$, S.D & $=11.74$ & & \\
\hline $\operatorname{Min} \quad=25.0$ & & & \\
\hline Max $=88.0$ & & & \\
\hline
\end{tabular}


Sex

Male

Female

Sub-Ethnic

Jakun

Education Level

No education

Primary

Secondary

Tertiary

Income Level

$<$ RM500

RM501 - RM1000

RM1001 - RM1500

RM1501 - RM2000

RM2001 - RM2500

Mean $=990.47$, S.D $=458.06$

Min $=400.0$

$\operatorname{Max}=4000.0$

$<5$

$6-10$

$11-15$

$>15$

0.6

Mean $=4.88$, S.D $=2.91$

Min $=0.0$

Max $=20.0$

Table 4 shows the distribution of main job and part-time job of respondents. Majority (31.2\%; 53 respondents) are rubber tapper as their main occupation. Some $(15.9 \% ; 27$ respondents) are gatherer, who obtained forest product to earn their living. Only a few of them venture into cash crop (farmers) $(2.9 \% ; 5$ respondents). The job as forest product supplier is second higher $27(15.9 \%)$. About 25.3 percent (43 respondents) are jobless and they depend on month dividend from ALDP as their main source of income.

Most of respondents are not having part-time job, (76.5\%; 130 respondents). Forest product supplier is the highest part-time job among respondents with 7.6 percent or 13 respondents.

Table 4. Main and part-time job of respondents $(n=170)$

\begin{tabular}{lcccc}
\hline & \multicolumn{2}{c}{ Main jobs } & \multicolumn{2}{c}{ Part-time jobs } \\
& $\mathrm{n}$ & $\%$ & $\mathrm{n}$ & $\%$ \\
\hline Rubber tapper & 53 & 31.2 & 7 & 4.1 \\
Forest product supplier & 27 & 15.9 & 13 & 7.6 \\
Self-employment & 24 & 14.1 & 7 & 4.1 \\
Salary worker & 10 & 5.9 & 2 & 1.2 \\
Oil palm worker & 6 & 3.5 & 3 & 1.8 \\
Cash crop farmer & 5 & 2.9 & 7 & 4.1 \\
Businessman & 2 & 1.2 & 1 & 0.6 \\
No job/ housewife & 43 & 25.3 & 130 & 76.5 \\
\hline
\end{tabular}


The ALDP farm size is not much different between these four RPS, whereby on average it is 6 acre per individual. Except for Buluh Nipis, the acreages is smaller, i.e 3 acre. Table 5 shows the distribution of respondents by type of cultivated land. From results, 52 (30.6\%) of respondents are cultivating the traditional land planting with rubber. Only 1.8 percent or 3 of them are cultivating their traditional land for orchard.

Table 5. Distribution of respondents by type of cultivated land $(\mathrm{n}=170)$

\begin{tabular}{lcc}
\hline \multicolumn{1}{c}{ Type of Cultivated Land } & Frequency (n) & Percentage (\%) \\
\hline ALDP oil palm plantation (by FELCRA and RISDA) & 170 & 100.0 \\
Rubber plantation (by RISDA) & 34 & 20.0 \\
Tradition land planting with rubber & 52 & 30.6 \\
Tradition land planting with oil palm & 11 & 6.5 \\
Tradition land planting with orchard & 3 & 1.8 \\
\hline
\end{tabular}

Meanwhile, Table 6 shows the distribution of land sizes. More than half of respondents (53.5\%; 91 respondents) has $3.1-6.0$ acre of land. For those who have farm land size more than 6 acre they used to plant rubber, oil palm and orchard.

Table 6. Distribution of respondents by farm land size $(\mathrm{n}=170)$

\begin{tabular}{lcc}
\hline Farm Land Size (Acre) & Frequency $(\mathrm{n})$ & Percentage $(\%)$ \\
\hline$<3.0$ & 24 & 14.1 \\
$3.1-6.0$ & 91 & 53.5 \\
$6.1-9.0$ & 29 & 17.1 \\
$9.1-12.0$ & 16 & 9.4 \\
$12.1-15.0$ & 4 & 2.4 \\
$>15.01$ & 6 & 3.5 \\
\hline
\end{tabular}

\subsection{Perceptions toward Agriculture Land Development Programme}

In this part, the respondents' perception toward ALDP which is divided into three sub-topics namely the perceptions toward objective of ALDP, development agencies and advantages of ALDP.

The results of the respondents' perceptions towards the ALDP objectives are presented in Table 7. Mean total value that is 2.980 shows the respondents have moderate perception toward objective of ALDP. Based on this study, it showed that many respondents seems to be agreed that the objectives of ALDP is to increase their income (mean $=3.629)$, to eliminate poverty $($ mean $=3.506)$, and to provide job opportunity $($ mean $=3.035)$.

On the other hand, the mean score for item Training programmes and courses in agriculture increased my knowledge of oil palm plantations and Provision and requirement of farm equipment received adequate are low with mean of 2.371 and 2.359 respectively. 
Table 7. Perception toward objective of ALDP $(n=170)$

\begin{tabular}{|c|c|c|c|c|c|c|c|}
\hline \multirow{2}{*}{ Statements } & \multicolumn{5}{|c|}{ Score Frequency (Percentage) } & \multirow{2}{*}{ Mean } & \multirow{2}{*}{ S.D } \\
\hline & 1 & 2 & 3 & 4 & 5 & & \\
\hline This programme has increased my income. & $\begin{array}{c}6 \\
(3.5)\end{array}$ & $\begin{array}{c}10 \\
(5.9)\end{array}$ & $\begin{array}{c}43 \\
(25.3)\end{array}$ & $\begin{array}{c}93 \\
(54.7)\end{array}$ & $\begin{array}{c}18 \\
(10.6)\end{array}$ & 3.629 & 0.883 \\
\hline $\begin{array}{l}\text { This programme can reduce the incidence of poverty } \\
\text { among Orang Asli. }\end{array}$ & $\begin{array}{c}13 \\
(7.6)\end{array}$ & $\begin{array}{c}15 \\
(8.8)\end{array}$ & $\begin{array}{c}34 \\
(20.0)\end{array}$ & $\begin{array}{c}89 \\
(52.4)\end{array}$ & $\begin{array}{c}19 \\
(11.2)\end{array}$ & 3.506 & 1.056 \\
\hline $\begin{array}{l}\text { This programme provides job opportunities for me } \\
\text { and my family. }\end{array}$ & $\begin{array}{c}28 \\
(16.5)\end{array}$ & $\begin{array}{c}27 \\
(15.9)\end{array}$ & $\begin{array}{c}37 \\
(21.8)\end{array}$ & $\begin{array}{c}67 \\
(39.4)\end{array}$ & $\begin{array}{c}11 \\
(6.5)\end{array}$ & 3.035 & 1.216 \\
\hline $\begin{array}{l}\text { Distribution of the provisions and requirements of } \\
\text { farm equipment received adequate. }\end{array}$ & $\begin{array}{c}50 \\
(29.4)\end{array}$ & $\begin{array}{c}42 \\
(24.7)\end{array}$ & $\begin{array}{c}48 \\
(28.2)\end{array}$ & $\begin{array}{c}25 \\
(14.7)\end{array}$ & $\begin{array}{c}5 \\
(2.9)\end{array}$ & 2.371 & 1.140 \\
\hline $\begin{array}{l}\text { Training programmes and courses in agriculture } \\
\text { increased my knowledge of oil palm plantations. }\end{array}$ & $\begin{array}{c}53 \\
(31.2)\end{array}$ & $\begin{array}{c}38 \\
(22.4)\end{array}$ & $\begin{array}{c}52 \\
(30.6)\end{array}$ & $\begin{array}{c}19 \\
(11.2)\end{array}$ & $\begin{array}{c}8 \\
(4.7)\end{array}$ & 2.359 & 1.169 \\
\hline Total & & & & & & 2.980 & 0.765 \\
\hline
\end{tabular}

The respondents' perceptions toward development agencies for ALDP (FELCRA, RISDA and JAKOA) are summarise in Table 8. Mean total (3.265) shows that respondents have moderate perception toward the development agencies. The respondents strongly believed that the agencies has the ability to develop agriculture land $($ mean $=4.000)$. The second highest mean score that is 3.624 where about $103(60.6 \%)$ of respondents agreed that the programme is constantly monitored by the development agencies.

However the respondents were not much agreed that the development agency always encourage Orang Asli to participate in development programme (mean $=3.141$ ) while at the same time listen to concern voiced by the participants (Orang Asli) (mean = 3.117) and also helped the participants in problems related to agriculture activities (mean=3.088). In contrast, the item The agency prefers employment opportunities to Orang Asli against foreign workers give the lowest $($ mean $=2.618)$.

Table 8. Perception toward agriculture agency (FELCRA and RISDA) $(\mathrm{n}=170)$

\begin{tabular}{|c|c|c|c|c|c|c|c|}
\hline \multirow{2}{*}{ Statements } & \multicolumn{5}{|c|}{ Score Frequency (Percentage) } & \multirow{2}{*}{ Mean } & \multirow{2}{*}{ S.D } \\
\hline & 1 & 2 & 3 & 4 & 5 & & \\
\hline $\begin{array}{l}\text { I believe the ability of the agencies to develop } \\
\text { agricultural land for programme participants. }\end{array}$ & $\begin{array}{c}4 \\
(2.4)\end{array}$ & $\begin{array}{c}2 \\
(1.2)\end{array}$ & $\begin{array}{c}14 \\
(8.2)\end{array}$ & $\begin{array}{c}120 \\
(70.6)\end{array}$ & $\begin{array}{c}30 \\
(17.6)\end{array}$ & 4.000 & 0.722 \\
\hline The programme is constantly monitored by agencies. & $\begin{array}{c}16 \\
(9.4)\end{array}$ & $\begin{array}{c}5 \\
(2.9)\end{array}$ & $\begin{array}{c}26 \\
(15.3)\end{array}$ & $\begin{array}{c}103 \\
(60.6)\end{array}$ & $\begin{array}{c}20 \\
(11.8)\end{array}$ & 3.624 & 1.049 \\
\hline $\begin{array}{l}\text { The agency always encourage the Orang Asli } \\
\text { participation in the programme. }\end{array}$ & $\begin{array}{c}18 \\
(10.6)\end{array}$ & $\begin{array}{c}38 \\
(22.4)\end{array}$ & $\begin{array}{c}42 \\
(24.7)\end{array}$ & $\begin{array}{c}46 \\
(27.1)\end{array}$ & $\begin{array}{c}26 \\
(15.3)\end{array}$ & 3.141 & 1.232 \\
\hline $\begin{array}{l}\text { The agency always listens to the concerns of } \\
\text { agriculture-related field of participants. }\end{array}$ & $\begin{array}{c}24 \\
(14.1)\end{array}$ & $\begin{array}{c}16 \\
(9.4)\end{array}$ & $\begin{array}{c}56 \\
(32.9)\end{array}$ & $\begin{array}{c}64 \\
(37.6)\end{array}$ & $\begin{array}{c}10 \\
(5.9)\end{array}$ & 3.117 & 1.124 \\
\hline $\begin{array}{l}\text { The agency has always helped the participants to } \\
\text { solve the problem on agriculture-related field aspect. }\end{array}$ & $\begin{array}{c}22 \\
(12.9)\end{array}$ & $\begin{array}{c}16 \\
(9.4)\end{array}$ & $\begin{array}{c}67 \\
(39.4)\end{array}$ & $\begin{array}{c}55 \\
(32.4)\end{array}$ & $\begin{array}{c}10 \\
(5.9)\end{array}$ & 3.088 & 1.082 \\
\hline $\begin{array}{l}\text { The agency prefers employment opportunities to } \\
\text { Orang Asli instead of foreign workers. }\end{array}$ & $\begin{array}{c}33 \\
(19.4)\end{array}$ & $\begin{array}{c}54 \\
(31.8)\end{array}$ & $\begin{array}{c}41 \\
(24.1)\end{array}$ & $\begin{array}{c}29 \\
(17.1)\end{array}$ & $\begin{array}{c}13 \\
(7.6)\end{array}$ & 2.618 & 1.197 \\
\hline Total & & & & & & 3.265 & 0.680 \\
\hline
\end{tabular}

Table 9 present the perception of respondents towards the advantages of ALDP. Mean total that is 3.106 shows moderate perceptions of respondents toward advantages of ALDP. The study discovered that $108(63.5 \%)$ of 
respondents agreed that farm is managed by the agency as the highest advantages (mean $=3.988)$. Meanwhile, $113(66.5 \%)$ of respondents agreed that the ALDP helps to develop the land for Orang Asli (mean = 3.924). Further, more than half of them (53.3\%; 91 respondents) of respondents agreed that ALDP give the opportunities for them to receive other financial incentives such as educational fund, money contribution and festival sponsor $($ mean $=3.565)$.

With the mean score of 3.218, the respondents were less agreed that their total monthly for an ALDP participant is higher than non-ALDP. This shows that they believe that non-ALDP can gain better income depend on their own effort. On the other hand, the respondents are agreed that ALDP is result in loss of traditional land, they are bound by contract (agreement) of the ALDP and result in reducing forest produce product with all this item have low mean $(2.347,2.147$ and 1.994 respectively).

Table 9. Perception toward the advantages of ALDP $(n=170)$

\begin{tabular}{|c|c|c|c|c|c|c|c|}
\hline \multirow{2}{*}{ Statements } & \multicolumn{5}{|c|}{ Score Frequency (Percentage) } & \multirow{2}{*}{ Mean } & \multirow{2}{*}{ S.D } \\
\hline & 1 & 2 & 3 & 4 & 5 & & \\
\hline Farm is managed by the agency. & $\begin{array}{c}9 \\
(5.3)\end{array}$ & 0 & $\begin{array}{c}14 \\
(8.2)\end{array}$ & $\begin{array}{c}108 \\
(63.5)\end{array}$ & $\begin{array}{c}39 \\
(22.9)\end{array}$ & 3.988 & 0.890 \\
\hline $\begin{array}{l}\text { This programme helps to develop the land for Orang } \\
\text { Asli. }\end{array}$ & $\begin{array}{c}4 \\
(2.4)\end{array}$ & $\begin{array}{c}4 \\
(2.4)\end{array}$ & $\begin{array}{c}21 \\
(12.4)\end{array}$ & $\begin{array}{l}113 \\
(66.5)\end{array}$ & $\begin{array}{c}28 \\
(16.5)\end{array}$ & 3.924 & 0.769 \\
\hline $\begin{array}{l}\text { Opportunity to receive other financial incentives } \\
\text { such as educational funds, money contributions and } \\
\text { festivals sponsor. }\end{array}$ & $\begin{array}{c}24 \\
(14.1)\end{array}$ & $\begin{array}{c}5 \\
(2.9)\end{array}$ & $\begin{array}{c}21 \\
(12.4)\end{array}$ & $\begin{array}{c}91 \\
(53.5)\end{array}$ & $\begin{array}{c}29 \\
(17.1)\end{array}$ & 3.565 & 1.225 \\
\hline Total monthly income higher than non-ALDP. & $\begin{array}{c}14 \\
(8.2)\end{array}$ & $\begin{array}{c}26 \\
(15.3)\end{array}$ & $\begin{array}{c}61 \\
(35.9)\end{array}$ & $\begin{array}{c}47 \\
(27.6)\end{array}$ & $\begin{array}{c}22 \\
(12.9)\end{array}$ & 3.218 & 1.112 \\
\hline $\begin{array}{l}\text { Participants continued to receive monthly dividends } \\
\text { without having to worry about no jobs. }\end{array}$ & $\begin{array}{c}25 \\
(14.7)\end{array}$ & $\begin{array}{c}22 \\
(12.9)\end{array}$ & $\begin{array}{c}48 \\
(28.2)\end{array}$ & $\begin{array}{c}48 \\
(28.2)\end{array}$ & $\begin{array}{c}27 \\
(15.9)\end{array}$ & 3.177 & 1.270 \\
\hline Land reserved under the name of the participant. & $\begin{array}{c}34 \\
(20.0)\end{array}$ & $\begin{array}{c}12 \\
(7.1)\end{array}$ & $\begin{array}{c}36 \\
(21.2)\end{array}$ & $\begin{array}{c}71 \\
(41.8)\end{array}$ & $\begin{array}{c}17 \\
(10.0)\end{array}$ & 3.147 & 1.295 \\
\hline Did not result in the loss of traditional land & $\begin{array}{c}32 \\
(18.8)\end{array}$ & $\begin{array}{c}84 \\
(49.4)\end{array}$ & $\begin{array}{c}29 \\
(17.1)\end{array}$ & $\begin{array}{c}13 \\
(7.6)\end{array}$ & $\begin{array}{c}12 \\
(7.1)\end{array}$ & 2.347 & 1.089 \\
\hline $\begin{array}{l}\text { Participants are not bound by contract (agreement) } \\
\text { of the ALDP }\end{array}$ & $\begin{array}{c}101 \\
(59.4)\end{array}$ & 0 & $\begin{array}{c}36 \\
(21.2)\end{array}$ & $\begin{array}{c}9 \\
(5.3)\end{array}$ & $\begin{array}{c}24 \\
(14.1)\end{array}$ & 2.147 & 1.510 \\
\hline Did not result in reducing forest produce product & $\begin{array}{c}43 \\
(25.3)\end{array}$ & $\begin{array}{c}98 \\
(57.6)\end{array}$ & $\begin{array}{c}17 \\
(10.0)\end{array}$ & $\begin{array}{c}11 \\
(6.5)\end{array}$ & $\begin{array}{c}1 \\
(0.6)\end{array}$ & 1.994 & 0.818 \\
\hline Total & & & & & & 3.056 & 0.421 \\
\hline
\end{tabular}

\subsection{Level of Perceptions toward ALDP}

Table 10 shows the level of respondents' perceptions toward ALDP. Overall, the respondents have moderate level of perception with the mean score of 61.994 . A total of 151 respondents $(88.8 \%)$ are at the moderate level. This figure denotes that majority of Orang Asli in the study area have a moderate level of perception toward ALDP. Only a small number (6 respondents; 3.5\%) have high level of perception toward the programme.

This is signed some things because the perception level of respondents towards this programme should be high after involved many years in ALDP. As discussed before, the perception is important because it influence the adoption of technology innovation as argued by Wyner (1974) and Holloway (1977).

Table 10. Distribution of respondents by level of perceptions toward ALDP $(n=170)$

\begin{tabular}{lcccc}
\hline \multicolumn{1}{c}{ Level } & Frequency & Percentage & Mean & S.D \\
\hline & & & 61.994 & 9.254 \\
Low $(20.0-46.0)$ & 13 & 7.6 & & \\
Moderate $(47.0-73.0)$ & 151 & 88.8 & & \\
High $(74.0-100.0)$ & 6 & 3.5 & \\
\hline
\end{tabular}




\section{Conclusion and Recommendations}

This study involved Jakun and Semelai sub ethnic group with total of 170 respondents from Pekan and Rompin District in Pahang, Malaysia. Most of the respondent's income is below than RM1000 per month include the dividend given and salary. The Orang Asli still depends on agriculture and forest to survive. However, as modernization encroached into their live, Orang Asli has to adopt and adjust their life, sociality and economically. When development through agriculture programme has brought to their doorstep, Orang Asli also has to change where commercial crop such as rubber and oil palm has become their choice of cultivation through forest produce were still in demand. ALDP is a modern agriculture programme introduced by government for the Orang Asli to participate.

This study revealed that the level of perceptions toward ALDP is moderate. Overall, the respondents have moderate level of perception with the mean score of 61.994. This is a good sign show that the minority group is also in the mainstream of the development process. Many respondents believe and confident that the ALDP programme has ability to make change in their life. This positive acceptance can influence their confidence and participation in ALDP in the long run. The positive perception among Orang Asli toward ALDP also portrays that they can adopt agriculture innovation in their economic life. This subsequently will give impact on the Orang Asli not only in economic matters but also in social aspect.

\section{Acknowledgements}

I begin by thanking Assoc. Prof Dr. Asnarulkhadi Abu Samah and Assoc. Prof. Dr. Norsida Man for their knowledge and support regarding this topic. Not forgotten, my lecturers and friends from Institute for Social Science Studies (IPSAS), UPM for their help and care. Also, special thanks to my parents and family. I have been blessed with a family that has always been there for me.

\section{References}

Abdul Jamak, A. B. S., Mohd Dali, N. R. S., Ahmad, S. Z., \& Yusuf, A. B. (2003). Entreprenuership among The Orang Asli Jakun (A Malaysian Aboriginal) in Rompin. Proceedings for Uniten Business Management Conference, COBM UNITEN.

Adam, M. F. M. (2002). Persepsi mahasiswa Universiti Putra Malaysia terhadap proses pembinaan negara-bangsa Malaysia. Master Thesis, Universiti Putra Malaysia.

Department of Statistic Malaysia. (2010). Population (Updated:31/07/2009). Retrieved from http://www.statistics.gov.my/

Edo, J., \& Fadzil, K. S. (2004). Socio-Economic Adjustments of the Aborigines: Malaysia. Building On Our Past And Investing In Our Future: An Internationa Seminar On Multidisciplinary Discource, jointly organized by Fo Guang University, Taiwan and The National University of Malaysia, Bangi, on $16-17^{\text {th }}$ February 2004, in UKM, Bangi, Selangor, Malaysia.

Fui, L. H. (1997). Orang Asli, Forest and Development. Malayan Forest Records, No. 43. Forest Research Institute Malaysia.

Fui, L. H. (2003). Economic Advancement and Poverty Eradication among the Aborigines inMalaysia. This is the original, unedited version of a paper submitted to the XII World Forestry Congress, Québec City, Canada.

Holloway, R. E. (1977). Perceptions of an innovation: Syracuse University Project Advance. (Doctoral dissertation, Syracuse University, 1977). Dissertation Abstracts International, (572-573A).

Idris, J. B. (1983). Planning and Administration of Development Programmes for Tribal Peoples (The Malaysian Setting). Kuala Lumpur: Center on Integrated Rural Development for Asia and the Pacific. (With the assistance of Mohd Tap Salleh, Jailani M. Dom, Abd. Haliam Haji Jawi, Md. Razim Shafie.).

JAKOA. (2010). Jabatan Hal Ehwal Orang Asli Malaysia. Program Pembangunan Ekonomi: State Economic Development Program. Retrieved February 22, 2010, from http://www.jheoa.gov.my/

Kotler, P. (2000). Marketing Manajemen: Analysis, Planning, implementation, and Control (9th ed.). Prentice Hall International, Int, New Yersey.

Lindesmith, A. R., \& Strauss, A. L. (1956). Social Psychology. New York: Holt Rinehart and Winston.

Nicholas, C. (2000). The Orang Asli and the Contest for Resources: Indigenous Politics, Development and Identity in Peninsular Malaysia. Kuala Lumpur: Vinlin Press Sdn. Bhd. 
Rahmat, J. (2003). Psikologi Komunikasi. Penerbit PT Remaja Rosdakarya: Bandung.

Rogers, E. M. (2003). Diffusion of innovations (5th ed.). New York: Free Press.

Wyner, N. B. (1974). A study of diffusion of innovation: Measuring perceived attributes of an innovation that determine rate of adoption. (Doctoral dissertation 1974), Dissertation Abstracts International, 3583A.

\section{Copyrights}

Copyright for this article is retained by the author(s), with first publication rights granted to the journal.

This is an open-access article distributed under the terms and conditions of the Creative Commons Attribution license (http://creativecommons.org/licenses/by/3.0/). 